\title{
Existências em transfiguração: olhares sobre a vadiagem e vidas transgressoras
}

\author{
Existences in transfiguration: \\ looks about the idleness and transgressors lives
}

\author{
Rodrigo Poreli * \\ Gabriel Giannattasio ${ }^{* *}$
}

\section{RESUMO}

Este artigo procura investigar e reinterpretar sujeitos singulares que atuaram contra o seu tempo, contra os costumes e a moral de sua época. As formas outras de readaptação ao mundo e encarar a vida através de novas possibilidades, constituem alguns atos e expressões de transgressão praticados por tais sujeitos. Dá-se destaque à figura do vadio, pois entendemos que sua vida está em constante transformação e renovação. Seu vaguear é uma criação e transfiguração da sua própria existência.

PALAVRAS-CHAVE: infames; singularidade histórica; vadiagem

\section{ABSTRACT}

The aim of this paper is to investigate and reinterpret singular individuals who have acted against their time, conventions and the moral of their epoch. Others different ways of readapting to the world and the seeking for new possibilities to think the life are some attitudes and expressions of transgression committed by these people. It is emphasized here the figure of vagrant because we are considering that his life is in continuous transformation and renovation. His wander is a kind of creation and transfiguration of his own existence.

KEYWORDS: infamous people; historic singularity; vagrancy

\section{Homofaber ou homo viator}

Uma das questões que inquieta a contemporaneidade diz respeito às relações entre o ócio e a tecnologia. Havia uma promessa que garantia que, quanto mais tecnológica fosse a sociedade, maior tempo livre disporia o homem. Segundo um diagnóstico do tempo presente somente uma parte do compromisso foi cumprida. Sim, vivemos em uma cultura altamente sofisticada. O Ocidente, com suas variações internas, jamais dispôs de tantos recursos de "dominação da natureza". Os braços, as mãos e o corpo do homem multiplicaram-se em um sem número de extensores: máquinas de trabalho e de

\footnotetext{
Mestrando em História, Universidade Estadual Paulista "Júlio de Mesquita Filho" (UNESP/Assis) e bolsista FAPESP / Brasil.

** Doutor em História. Professor da Universidade Estadual de Londrina (UEL) / Brasil.
} 
guerra, satélites, robótica, veículos de comunicação, tudo concorrendo para intensificar o instante e valorizar o tempo.

Pensava-se que todos estes fatores contribuiriam para a geração de um homem mais liberto das necessidades. Que o trabalho compulsório poderia ser executado pelas suas criações, entronizando, desta forma, uma nova espécie de homem, não mais embrutecido pelas obrigações do ganha pão. $\mathrm{O}$ homem do trabalho, docilizado, disciplinado, obediente, repetitivo e previsível, não só foi mantido em seu posto, como agregou novos contingentes: as mulheres foram seduzidas pelo fetiche, o tempo e os corpos das crianças foram sendo colonizados cada vez mais precocemente. A vida útil estende-se na velhice e nos manicômios. Presídios e asilos colonizam os "alienados" com as terapias ocupacionais. É preciso preencher o tempo, agenciar preocupações, projetar tarefas, programar o que virá, nenhum instante deve escapar ao cálculo, afinal, cabeça vazia e o tempo entregue "ao deus dará" são a "oficina do diabo".

As cenas de nossa contemporaneidade estão repletas de crianças estressadas, exaustas, assoberbadas com atividades lúdicas, esportivas, educativas, culturais e de lazer...ufa! Ocupar o tempo é a palavra de ordem, daqui eu já vou para ali, de lá eu já vou acolá, nenhum instante de hesitação. Quem hesita perde, perde o bonde, perde a vaga, perde dinheiro, perde tempo, perde o fluxo. O seu tempo livre? As suas férias? O seu descanso? Não se preocupe, nós os programamos para você!

Com tanta tecnologia, a vida está sendo aquartelada! Se somos constituídos pela linguagem, desde que nascemos, somos, ainda, prisioneiros do tempo útil. Assim, nada mais saudável aos ouvidos do que a frase: "não se trata de nada fazer, mas de fazer o nada". Esta é a divisa dos organizadores do "Dia do Nada", um dos temas que iremos ora tratar.

\section{O Vagamundo}

Este trabalho procura investigar e construir novos sentidos para sujeitos singulares que atuaram contra o seu tempo. O nosso intuito não será o de estudá-los tomando-os como produto da sociedade ou em sintonia com o seu tempo. Nem pretendemos reconhecê-los como expressões dos excluídos.

O que nos tem causado interesse são as inúmeras formas de transgressão 
criadas pelo homem, e que, de uma forma ou de outra, ainda tocam as nossas modernas existências. A transgressão deve ser vista não como uma força negativa e reativa às várias formas de poder, mas deve ser entendida na condição de uma força positiva, ou seja, de uma aliança do necessário com o impossível.

Os vadios são tomados, aqui, como pessoas transgressoras e, mais, as suas vidas, assim como as expressões de suas existências, permanecem estranhas à cultura da coletividade. Por essa perspectiva, a vadiagem poder ser vista como uma vida errante, venturosa, ociosa, sem teto e sem recursos. Já como ilícito penal, consiste em um mecanismo de controle do Estado sobre a liberdade do indivíduo.

\section{Normas e Legislações Punitivas}

Dessa maneira, podemos encontrar, ao longo da história, uma recorrente preocupação dos governantes e da sociedade em controlar os comportamentos dos chamados vadios, vagabundos, errantes. Vadiagem corresponde à vagabondage do direito francês. Na Grécia, a mendicância era punida por meio de uma legislação inspirada na do Egito. A lei de Atenas exigia que todo cidadão justificasse os seus meios de subsistência e excluía da cidade os que não trabalhavam (RIBEIRO, 2004).

No Direito Romano, segundo Ulpiano, o procônsul tinha o poder de banir da província os homens de má fama e perigosos: "Congruit bono et gravi praesidi curare ut peccata atque quieta província sit quam regit; quod non difficile obtinebit si sollicite agat ut malis hominibus província careat eosque conquirat". ${ }^{1}$ Clarus definiu o vagabundo: "ille qui non certum habet domicilium in quo habitet”2 e Farinácio serve-se da expressão análoga: "vagabundus proprie dicitur qui per mundum vagatur nec certum habet domicilium in quo habitet"3 (DUARTE, 1956: 269).

No Brasil, encontramos o crime de vadiagem já nas Ordenações Filipinas

\footnotetext{
1 Para que a província fosse calma como quando era governada pelo bom e forte chefe, concordou-se em se vigiar os erros, o que não seria difícil se, com cuidado, se recrutasse e expulsasse da província os homens maus, abstendo-se deles.

2 Aquele que não tem domicílio certo para habitar.

3 Vagabundo, particularmente, é dito daquele que vaga pelo mundo sem ter domicílio certo para morar.
} 
de 1603. Lei n. ${ }^{\circ}$ V, Título LXVIII, "Dos Vadios”:

Homem que não viver como senhor, ou como amo, nem tiver ofício ou outro mister em que trabalhe, ou ganhe a sua vida, ou não andar negociando, algum negócio seu ou alheio, ou dentro de 20 dias, chegado a um lugar, não tiver amo ou ofício, será preso e açoitado (Ibidem: 271).

Nesse tempo, os sujeitos passivos destes ilícitos eram os escravos, ou seja, os negros, mulatos e os brancos de situação menos remediada. Todavia, não somente os escravos e os libertos, mas todos aqueles que não se enquadrassem na relação senhor-escravo. O Código Criminal do Império, de 1830, também punia a vadiagem:

Art. 295. Não tomar qualquer pessoa uma occupação honesta e util de que possa subsistir, depois de advertida pelo juiz de paz, não tendo renda sufficiente. Penas - de prisão com trabalho por oito a vinte e quatro dias. Ao criminoso autor: Maximo - 24 dias de prisão com trabalho. Médio - 16 dias, idem. Mínimo - 8 dias, idem. Se não houver casa de correcção: Maximo - 28 dias de prisão simples. Médio - 18 dias e 2/3, idem. Mínimo - 9 dias e 1/3, idem (RIBEIRO, 2004).

No Código Penal da República (1891), a punição foi aumentada em relação à cominada no Código Penal do Império, consistindo em trabalhos forçados e pena privativa de liberdade. Após o cumprimento da pena, o infrator, ainda, deveria prestar compromisso de não permanecer na situação de vadiagem (Ibidem).

O Código Penal de 1940 retirou o tipo penal da vadiagem do seu âmbito específico, remetendo-o ao disciplinamento pela Lei das Contravenções Penais. Coube, a este Código Penal, introduzir, no Brasil, a classificação bipartida dos ilícitos penais em crimes e contravenções. O tipo passou então a ser disciplinado como contravenção prevista no artigo 59 da referida lei:

Vadiagem: Art. 59 - Entregar-se alguém habitualmente à ociosidade, sendo válido para o trabalho, sem ter renda que lhe assegure meios bastantes de subsistência, ou prover a própria subsistência mediante ocupação ilícita: Pena - prisão simples, de 15 (quinze) dias a 3 (três) meses. Parágrafo único - A aquisição superveniente de renda, que assegure ao condenado meios bastantes de subsistência, extingue a pena (Ibidem).

Para um melhor entendimento desses fatos, pautamo-nos, num primeiro momento, na análise de inquéritos policiais e processos judiciais elaborados frente à detenção e condenação de diversos sujeitos por vadiagem. Todas essas fontes se encontram no Centro de Documentação e Pesquisa em História, localizado na Universidade Estadual de Londrina.

A documentação analisada refere-se à cidade de Londrina nas décadas de 
1950 e 1960. Nesse período, essa cidade estava em fase de expansão econômica e política, devido ao crescimento da produção agrícola (cafeeira) e industrial. Foram pesquisados quinze processos de vadiagem. ${ }^{4}$ Em cada um deles, pode-se notar que os vadios eram sempre de fora da cidade de Londrina, pois vinham, segundo eles mesmos, em busca de um trabalho lícito e digno.

Pela leitura dos autos, a polícia fazia "batidas" pelas ruas da cidade com a finalidade de eliminar uma casta de homens não-trabalhadores que, segundo as falas de delegados, promotores e juízes, estava proliferando na cidade de Londrina nessa época. Pessoas que estavam em lugares suspeitos, como a "zona do baixo meretrício" e perto de estações ferroviárias e rodoviárias, eram consideradas vadias em potencial.

Quando presos esses indivíduos eram sempre submetidos a uma triagem pessoal. Eram anotados desde os atributos físicos (altura, cor dos olhos, sinais no corpo) até os atributos morais (vícios em geral). Eram acusados de não possuírem trabalho e de praticarem pequenos furtos. Os termos usados nos processos eram sempre os mesmos: "vadio", "punguista”, "chorro" e "lanceiro".5

Da prisão até a condenação, havia, praticamente, duas ou três audiências com o acusado e as autoridades judiciárias. Era designada uma audiência para a descrição dos fatos que originaram a prisão do réu. Nas audiências, pode-se perceber que as falas dessas autoridades e das testemunhas eram "construídas", pois usavam as mesmas expressões e termos para tratar com o acusado. Esse, por sua vez, tinha pouca voz no processo. Quando lhe era permitido falar, recusava-se a admitir a condição de vadio.

Em relação à sua defesa, eram nomeados advogados que apenas faziam uma defesa técnica, na qual eram negadas as acusações. Poucas provas eram produzidas por ambas as partes. O Estado, muitas vezes, era autoritário, pois, nos casos estudados, apenas três acusados foram absolvidos. Os outros foram condenados a dois ou três meses de prisão. Depois desse tempo, eram postos em liberdade. Na verdade, essa situação funcionava mais como uma medida social do que jurídica.

Pelas análises acima, podemos afirmar que o ilícito da vadiagem está

\footnotetext{
4 AUTOS pesquisados sobre vadiagem em Londrina nas décadas de 1950 e 1960: n. ${ }^{\circ} 8.234 / 58$, 9.139/60, 9.734/61, 9841/61, 169/62, 184/62, 186/62, 1.0605/62, 45/63, 19/64, 65/64, 136/64, $146 / 64,19 / 66$ e $35 / 66$.

5 Esses termos pejorativos designavam o vadio como ladrão ou "batedor de carteiras".
} 
relacionado à produção de riquezas, ao trabalho, à ocupação do tempo de forma produtiva, o que, conseqüentemente, afastaria o uso ilícito da liberdade. Para a lei penal brasileira, vadio é quem não trabalha.

O historiador Erivan Cassiano Karvat (1998) mostra-nos que o respeito, a ordem, ao trabalho, ao progresso e a civilização constituem noções ou normas fundamentadoras da própria sociedade. A inserção no mundo do trabalho garantia o próprio reconhecimento do indivíduo, ou seja, a sua cidadania. Ao contrário, a vadiagem, na sua suposta negação ao trabalho, simbolizava a recusa àquela que era considerada a norma fundamental da própria existência social. Dessa forma, o trabalho representa a lei suprema da sociedade. Está ligado ao desenvolvimento dos atributos sociais e morais. Inversamente, a vadiagem está associada à imoralidade e à perversão. Vadios são representantes das práticas de negação do trabalho e seres anti-sociais (Ibidem: 31).

O uso do termo vadiagem também está muito relacionado ao espaço público e, por isto mesmo, a um modo de vida ameaçador à ordem social. Um estado permanente de perigo que colocava em risco os bons costumes. Nesse sentido os vadios representam uma forma de transgressão e um questionamento da ordem vigente (MARTINS, 1998: 74).

Até aqui, a vadiagem apresenta-se enquanto signo carregado de negatividade. Ela constitui uma ausência, uma falta, uma carência. $O$ vadio não tem trabalho, não tem cidadania, não exerce sua tarefa social. Ele é identificado a estes múltiplos nãos! E ele próprio se recusa a este papel. Em todos os processos analisados, ele não quer vestir a máscara da vadiagem.

\section{Ser, transgressão e estilos de vida.}

Em seu ensaio sobre $A$ vida dos homens infames, Michel Foucault faz o que chama de uma "antologia de existências" de vidas singulares, das quais recolhe "fragmentos de discursos e fragmentos de uma realidade da qual fazem parte". Trata-se, segundo o autor, de personagens que pertencem "àqueles milhões de existências que estão destinadas a não deixar rastro" e o que as "arranca à noite em que elas poderiam, e talvez devessem sempre, ter ficado, é o encontro com o poder: sem este choque, é indubitável que nenhuma palavra teria ficado para lembrar seu fugidio trajecto" (FOUCAULT, 1992: 96-7). 
Então, desejamos compreender e reconhecer a vadiagem como expressão de sujeitos singulares que atuam ou atuaram contra a moral de sua época. São sujeitos que não conseguiram dizer não à natureza, ou cuja "dobra da moral” foi incapaz de deter o ato "antropofágico". São existências singulares e homogêneas, quanto ao delito criminoso que as configurou como "homens infames". Esse fato nos permite criar novas possibilidades interpretativas, acompanhar rupturas e continuidades existentes em suas vidas singulares, pois o vadio é, aqui, um extemporâneo, um transgressor.

E essa transgressão, como diz Foucault, não é violência em um mundo partilhado (em um mundo ético) nem triunfa sobre limites que ela apaga (em um mundo dialético ou revolucionário), ele toma, no âmago do limite, a medida desmesurada da distância que nela se abre e desenha o traço fulgurante que a faz ser. Nada é negativo na transgressão. Ela afirma o ser limitado, afirma o ilimitado no qual ela se lança, abrindo-o pela primeira vez à existência (FOUCAULT, 2001: 33).

Diante de uma cultura que se deseja positiva, lisa, sem asperezas, do desenvolvimento tecnológico, da ideologia econômica uniformizante que reina como mestra, e de uma sociedade que se afirma perfeita e plena, o sociólogo francês Michel Maffesoli, (2001: 23) defende a prática do nomadismo pelas sociedades contemporâneas. Esse autor interpreta-o como uma forma de vadiagem e vagabundagem, que tende a ser totalmente antitético e transgressor em relação à forma de Estado moderna. Esse nomadismo nada mais é que uma errância, menos ofensiva, um tanto lúdica, repousando sobre a intuição da impermanência das coisas, dos seres e de seus relacionamentos (Ibidem: 29).

$\mathrm{Na}$ contemporaneidade o homem começa a se tornar um ente do universo em constante dispersão, e com isso efetua-se o sepultamento do sedentarismo e, de forma curiosa, inventa-se uma nova vadiagem. O homem pós-moderno é um ente que se liberta da fixação ao lugar, é alguém ansioso que almeja, não um retorno às origens, mas a reinvenção dessa origem.

Vadiagem é a causa e o efeito de uma liberdade de pensamento, de atitudes e de costumes. Desejo de evasão que incita à mudança de lugar e de hábitos. Viver a vida sem metas ou objetivos a serem atingidos, ou pelo menos, vivê-la com uma tal plasticidade que permita agregar, inovar o cotidiano, receber o acaso, o imprevisto, como a alegre experimentação do novo (Ibidem: 108). 
Dessa maneira, a transgressão pode ser entendida como uma força em permanente vir-a-ser. Ela transcende a nossa existência. A vadiagem está sendo apropriada, aqui, como o ato de entregar-se ao destino, como a recusa de submeter a existência às formas de programação, à colonização do tempo. $\mathrm{O}$ vadio não é um homo faber, mas sim um homo viator. É um viajante sempre com sede e em busca do infinito (Ibidem: 107).

Inúmeras pessoas, sejam elas poetas, pensadores, professores, homens e mulheres, debruçaram-se sobre uma errância e enfatizaram a existência em seu perpétuo recomeço: uma vida mais aberta, pouco domesticada, sempre e outra vez antiga e atual. A experiência mais radical da vadiagem traduz-se no ato de submeter o próprio corpo ao exercício de uma ociosidade sem finalidade, de transfigurar o corpo que vagueia pelo mundo. A transgressão sobre si mesmo é uma linha de fuga e de transcendência em relação aos códigos instituídos.

Assim, admitir a vadiagem é o mesmo que tomar a transgressão como aceitação jubilosa da imprevisibilidade da vida humana. Ao invés de moralizar, aponta-se para um processo de estetização da vida cotidiana, que está implicada na noção de estética da existência, não como embelezamento, mas como construção de uma ética individual. O indivíduo como esteta de si mesmo é como o homem que talha em contato com outros: "A existência como obra de arte, regras ao mesmo tempo éticas e estéticas que constituem estilos de vida" (DELEUZE, 1992: 123).

Esse entendimento entre arte e vida está presente em algumas obras de Nietzsche e, mais ainda, nos escritos de Foucault. No primeiro, pode-se perceber, em $O$ nascimento da tragédia, a frase emblemática sobre estética da existência: "pois só como fenômeno estético podem a existência e o mundo justificar-se eternamente" (NIETZSCHE, 2003: 47). Mais adiante, a arte aparece como feiticeira da cura, com o poder de transformar os pensamentos sobre o horror da existência em representações sublimes e cômicas, com as quais é possível viver (Ibidem: 55-56).

Esse autor, na sua crítica ácida ao declínio da tragédia grega, questiona, também, as nossas ambições de conhecimento verdadeiro, a insistente "vontade de verdade". Para pensarmos a vida, a ciência e a nossa própria existência, não sejamos tão sérios, exijamos a estética: trágica, dissonante, embriagada pela música dionisíaca. Em outra obra, A gaia ciência, a arte e a própria vida 
humana estão mais próximas, assim como permanece a constante crítica nietzscheana à "vontade de verdade" É a arte uma espécie de culto ao nãoverdadeiro, à boa vontade de aparência. No aforismo intitulado Nossa última gratidão para com a arte, Nietzsche convoca os homens sérios e sóbrios a uma serena e artística distância de si mesmos. Ele diz: "precisamos usar de toda arte altiva, flutuante, dançante, zombeteira, pueril, e bem-aventurada, para não perdemos aquela liberdade sobre as coisas que nosso ideal exige de nós" (NIETZSCHE, 1999: 182).

Já o trabalho de Foucault (2005: 350) começa por um estudo dos domínios ou eixos nos quais o sujeito se constitui: o poder, o saber e a ética, ou, dito de outra forma, as relações com os outros, com a verdade e consigo mesmo. Ele entende que, nesses domínios, exercem-se práticas de dominação e práticas de liberdade. $\mathrm{O}$ estudo de tais práticas, a ontologia histórica de nós mesmos, indica-nos como fomos constituídos como sujeitos que exercem e sofrem relações de poder e como nos constituímos como sujeitos morais de nossas ações.

Essa ontologia de nós mesmos não pode ser considerada como uma teoria ou doutrina, nem mesmo um corpo de saberes. Há que considera-la como um ethos. Por isso, para esse autor: "uma vida filosófica em que a crítica do que somos é simultaneamente análise histórica dos limites que nos são colocados e prova de sua transgressão possível" (Ibidem: 351).

Uma estética da existência, propiciaria uma maior possibilidade de escolhas pessoais, convidaria a considerar a própria vida como uma obra de arte e proporia uma ética do estilo, o que se acha possibilitado e limitado pelos domínios do saber e pelas construções normativas que constituem o indivíduo como sujeito e objeto de determinados conhecimentos e poderes. A escolha é possível, porém, tem-se, como pano de fundo, o sistema, os jogos de verdade e os dispositivos de poder. Esta constatação converte a estética da existência em um modo de ver a ética, que tem como características a crítica e a experimentação.

Enquanto modo crítico, a estética da existência encontra, em sua base, o fato de que os domínios de saber e os dispositivos de poder, que condicionam a experiência e desenham a margem de possibilidades da época, não são necessários nem imutáveis. Isto quer dizer que os limites impostos evidenciam- 
se como tantos outros lugares de transgressões possíveis, que devem ser pensados com atenção, tendo em vista a sua radical contingência. $O$ que a experiência histórica mostra é o fato de que os limites são variáveis e os fundamentos, mutáveis. A escolha do estilo deve questionar a experiência que constitui o atual sistema de relações (NASCIMENTO, 2006).

Assim, para essa filosofia, entendida como prática, o presente é contingência que nos configura e também nos possibilita a transgressão. Por essa razão, o trabalho ascético do indivíduo sobre ele mesmo, que transforma suas relações com os outros e com a verdade, é um exercício de liberdade que transgride os limites da contingência. Sendo ainda, um exercício, por meio do qual, o sujeito desprende-se de si, convencido de que, no presente, existem mais liberdades possíveis, mais possibilidades de recriar o futuro do que se pode imaginar (Ibidem).

\section{Vidas errantes e idéias vagueantes}

Podemos perceber, em diferentes épocas, pessoas, indivíduos e grupos com esse desejo de viver a vida na sua intensidade, de inventar e realizar, em suas ações, seus próprios valores. Um exemplo notável foi Diógenes de Sinope (400-325 a. C) que era pertencente ao movimento dos chamados "cínicos". Esse indivíduo que vive em um universo sujeito aos seus caprichos, trazia uma mensagem filosófica que garantia a felicidade. O cinismo, influenciado pelas idéias do filósofo Antístenes, precursor desse movimento, é marcado pela experiência existencial de Sócrates, no que tange à sua independência de caráter, mas muito pouco afeito à filosofia de Platão, na medida em que negava a transcendência das idéias (GOULET-CAZÉ, 2003: 260-261).

Os cínicos desprezavam as artes, os ensinamentos, a matemática e as ciências naturais. Consideravam-se cidadãos do mundo, não de uma determinada cidade ou região, por isso, eram contra a guerra e a política. $\mathrm{O}$ cinismo, mais do que uma filosofia, consistia, sobretudo, em um(a) estilo de vida. Viviam da mendicância, privando-se de quase tudo. O objetivo de vida dos cínicos era o bastar-se a si mesmo. Tinham como virtude a liberdade da palavra e falavam tudo sem disfarce, com ironia e arrogância.

Se Antístines é o fundador da "escola cínica”, foi seu discípulo, Diógenes de 
Sinope, quem levou às últimas conseqüências as suas idéias, dando nova força ao movimento. Foi através de seu rigoroso estilo de vida, uma vida extremamente simples, que Diógenes transmitiu os seus ensinamentos. Uma grande barrica ou um grande vaso de barro servia-lhe de abrigo, vestindo-se com trapos e vivendo de esmolas. Autodenominava-se "o cão", pois queria ter uma vida simples e livre como este (BERNARDI, 2005).

Assim, Diógenes reivindica, de saída, a diferença. Ele é aquele que fala e se comporta de outro modo, que entra no teatro quando todos saem ou que vagueia andando para trás, sob os pórticos. Sua atitude exige uma conversão radical, fundada sobre a referência ao animal, ao retorno à natureza, à recusa do espírito de seriedade, isto é, à subversão generalizada dos valores corretamente respeitados em todos os domínios do agir humano.

Para provar que as necessidades básicas eram naturais, da mesma forma que comia na praça pública, também se masturbava. Apenas lamentava que a fome não desaparecesse apenas esfregando a mão na barriga. De todos os relatos sobre Diógenes, verdadeiros ou ficcionais, um dos mais conhecidos é o seu encontro com Alexandre o Grande. Tendo possuído como tutor Aristóteles, Alexandre era um grande admirador e patrocinador dos filósofos, por este motivo, em sua passagem por Corinto, fez questão de procurar o cínico. Pela manhã o Imperador encontra o filósofo recostado em seu abrigo. Dirigindo-se a ele Alexandre pergunta-lhe: "Pede-me o que quiseres". Diógenes responde: "Não me faças sombra. Devolve meu sol" (Ibidem).

Mais tarde, sob o império romano, a influência do pensamento cínico conheceu uma extraordinária retomada e se tornou a filosofia popular por excelência. É no século I, com Demétrio, o amigo de Sêneca, que, pela primeira vez, a existência de um filósofo cínico é percebida em Roma. O cinismo romano ocupou um lugar importante na cena filosófica desse período, influenciando o surgimento dos estóicos, com destaque para Sêneca, que foi um dos principais representantes do estoicismo romano. Para ele, o homem deve aprimorar seu espírito e ser capaz de conduzir a sua vida com superioridade. Dominar as ambições egoístas, libertar-se dos próprios desejos materiais e não se deixar levar pela cobiça do poder são princípios que conduzirão a uma existência de satisfação interior e respeito à natureza e aos homens.

O envolvimento com a política e a intensa participação na vida pública do 
Império (que ele praticamente dirigiu, como preceptor de Nero) não o impediram de realizar uma obra filosófica de notável solidez, voltada, principalmente, para a reflexão sobre as questões morais. A filosofia é um saber prático que visa curar, moralmente, o homem, ensinando-o a cultivar a virtude e a constância e, sobretudo, a viver em consonância com as leis da natureza. Em suma, "a filosofia deve ensinar a viver e não a fazer discursos" (SÊNECA, 2002: 4).

Contudo, é na Idade Média que se nota uma maneira muito peculiar de viver e entender o mundo a sua volta. Um desses modos de vida e maneiras de pensar se traduz na idéia de circulação e locomoção intensa, uma espécie de nomadismo que perpassa todas as camadas sociais, como a epopéia das cruzadas, por exemplo, que para além das motivações religiosas indica uma inegável sede por outro lugar. Todas as classes sociais foram dominadas por um sentimento vago de inquietação que as incitava a buscarem novas e remotas regiões, movidas por fantásticas aspirações de uma nova vida. Daí o fanatismo pelas viagens ao Oriente, pelas Cruzadas, pelas peregrinações, pelas expedições longínquas e perigosas (MAFFESOLI, 2001: 48-49).

Um termo genérico empregado na Idade Média para designar formas diferentes de nomadismo é goliardo. Receberam esse nome, talvez desde o século IX, seguramente desde o século XII, os clérigos indisciplinados ou sem prebenda (renda eclesiástica), que viviam irregularmente e sem pouso. A origem do termo não está, ainda, estabelecida. Alguns identificam os goliardos com Pedro Abelardo (1079-1142), chamado, nos processos que lhe moveu a Igreja, de Golias, inimigo da fé. Outros, ao fato deles beberem e comerem como Golias (Ibidem).

Esta referência específica valia-lhes, também, a classificação de vagueantes, itinerantes, mendigos, errantes ou vagabundos. Freqüentemente acompanhados de mulheres, aplicavam seus talentos literários e seus dons poéticos na composição de versos satíricos, de conteúdo antipapal e erótico. A sua produção literária constituiu um dos marcos precursores do Renascimento. Os famosos Carmina Burana ${ }^{6}$ foram escritos pelos goliardos, esse grupo

\footnotetext{
6 Cantata cênica de poesias latinas medievais, feita para ser representada e dançada, posta sobre textos em latim e alemão, que foram extraídas de uma colocação de duzentas peças poéticas diversas compiladas pelo final do século XIII. A palavra Carmina é o plural de Carmen (em português, Canção). O título inteiro significa literalmente: Canções dos Beurens. Esta
} 
profano de errantes.

Nas grandes cidades européias da época, e mais precisamente em Paris, os goliardos reencarnavam os valores dionisíacos por meio de seus ritos específicos, como bebedeiras, badernas, devassidão. Estes monges e menestréis desgarrados passavam o seu tempo deliciando-se com os prazeres da carne e os poemas que eles deixaram faziam a crônica de suas obsessões, por vezes, chegando à obscenidade.

O historiador polonês Bronislaw Geremek (1995: 303-304) que estuda a literatura medieval enquanto construtora de um discurso próprio em torno dos tipos do "vagabundo", do "vigarista" e do "mendigo", diz que a imagem dos grupos marginais na Idade Média era construída com base na noção estamental e hierárquica de organização, própria da estrutura social da época. A mendicância, a vagabundagem e a errância eram tratadas como profissão. Essas figuras eram vistas como integrantes de uma organização corporativa. Sua composição hierárquica, linguagem específica, costumes e espaços diferenciados bastavam para sentenciar um Estado dentro do Estado, ou seja, um antiEstado.

No Renascimento, a figura emblemática de François Villon pode ter sido influenciada pelo modo de ser dos goliardos. Poeta francês, dono de versos líricos de esmerada beleza e originalidade, compôs baladas e rondeau. Entre suas obras menores, cabe destacar alguns poemas escritos na gíria dos delinqüentes. Sua vida foi a mais estranha das simbioses: o mais hábil e vil ladrão de Paris e o maior poeta da França de seu tempo. Aos 20 anos, já havia seduzido muitas mulheres, e aos 24, assassinado um padre, aos 25, tornava-se um dos principais membros da Conquille (Cavalheiros do Punhal), bando de trapaceiros, salteadores de estradas, assassinos e rufiões que fizeram do século XV uma época singular (AGUIAR, 2005).

Sua educação começou pelo furto. Leitura e escrita vieram depois. Ficou órfão de pai muito cedo e aos 12 anos sua mãe o entregou à generosidade do padre Guilhaume de Villon, parente distante, que deu a François o seu próprio

última palavra se refere ao fato de que os textos escolhidos para esta cantata secular foram descobertos em 1803, em um velho mosteiro beneditino da Baviera, em Benediktbeuren, no sudoeste da Alemanha. Esta cantata é emoldurada por um símbolo da Antigüidade, o conceito da Roda da Fortuna, eternamente girando, trazendo alternadamente boa e má sorte. É uma parábola da vida humana exposta à constante mudança. Disponível em <http://www.spectrumgothic.com.br/musica/carmina.htm>. Acesso em 25 jun. 2006. 
nome. Com a esperança de fazer dele um sacerdote, matriculou-o, em 1443, na Universidade de Paris, onde ele conseguiu o título de bacharel e professor, saindo da Universidade como excelente aluno, poeta inspirado e campeão de velhacaria. Passava as tardes em trabalhos de criação literária, as noites em devassidão e roubos e, as manhãs, a dormir (Ibidem).

Durante longo tempo, entrou e saiu sorrateiramente pela porta dos fundos de várias cidades e aldeias. Quase sempre dormia sobre montes de feno e celeiros desertos. Detinha-se, às vezes, para comer qualquer coisa nas tabernas rurais, divertindo os simplórios com seus versos obscenos e lhes esvaziando os bolsos enquanto estavam boquiabertos de admiração pela sua pessoa. Preso várias vezes e condenado à forca, François Villon nunca procurou fugir do convívio com a miséria humana. Ao contrário, sorveu sua amarga taça junto à humanidade até a última gota (Ibidem). E, como expressão deste universo de vagamundos, não poderia ter destino mais exemplar, simplesmente, desapareceu, sem deixar rastros, no ano de 1463.

Séculos mais tarde, esse espírito de contestação e celebração ao paradoxo da vida, com suas alegrias e mazelas, é retomado pelo movimento Romântico do século XIX. Será, também, através dele -o romantismo- que se conhecerá uma continuidade resignificada dos desejos de evasão. Com o concurso da imaginação, o homem pode deslocar-se sem nem mesmo sair de seu espaço físico, lembrando-se de que um marco da literatura romântica é um livro de Xavier de Maistre intitulado Viagem à roda do meu quarto.

Centrado no traço subjetivo/individual, o movimento romântico, como representação de uma individualidade conflitante, torna-se complexo e escapa a uma definição exata e totalizadora, refletindo a inquietação do homem inserido no mundo. O romântico vive a contradição em seu grau máximo, pois, ao negar a realidade, nega a si próprio.

O poeta romântico não quer pensar o mundo objetivamente, mas senti-lo em sua plenitude. A obra deve refletir aquilo que o Eu sente em relação ao mundo. Permeada por uma rebeldia latente, tal postura proporciona ao movimento uma pluralidade expressiva, uma vez que o $\mathrm{Eu}$ muda sua perspectiva individual com o posicionamento do sujeito diante do mundo. Daí termos, nesse movimento, uma grande variedade de manifestações que lhe acabam outorgando uma enorme gama de possibilidades expressivas. 
Particularmente, no século XX e XXI, existiram e existem inúmeros movimentos, grupos e tendências, geralmente no campo das artes, da filosofia e da literatura (As vanguardas européias do início do século, as agitações artísticas e culturais dos anos 60-70, entre outros), que vão expressar reinterpretações, críticas e transgressões a valores e costumes instituídos. Se demos destaque a alguns destes instantes da história e se passou ao largo de outros, só o caráter arbitrário da escolha pode justificar. Mas, se assim procedeu-se, foi para que se estabelecessem dois contrapontos na história: um primeiro, no qual a vadiagem se apresenta como valor propositivo, afirmativo, e um segundo, em que o exercício da vadiagem torna-se um valor reativo e negativo. É a partir desta história e desta dinâmica processual que se procurará analisar a produção artística e "performática" do movimento denominado "Dia do Nada”, existente em Londrina, no estado do Paraná.

\section{O "Dia do Nada": a arte como questionamento e continuidade da vida.}

O "Dia do Nada" é um evento singular que vem acontecendo desde 2002, criado pelo artista plástico residente em Londrina, Rubens Pileggi Sá, que também faz poesia, fotografa e escreve no jornal Folha de Londrina, há cinco anos, sobre arte contemporânea. Esse movimento reúne artistas e não-artistas em diversas cidades e na internet para uma reflexão sobre o ócio em nossa sociedade. O vazio existencial de que falam os filósofos e o absoluto na supressão de um tempo e espaço físicos, para a criação de trabalhos em arte, são inspiradores desse tema (SÁ, 2005)

O evento não é contra o trabalho, ele é contra o trabalho desprazeroso, mecânico, robotizado, alienado. Não defende o ócio, é contra a ganância. Não se opõe às atividades policiais, é a favor da liberdade. Não é, tampouco, protesto ou reivindicação, mas reconhece o caráter perturbador de um assunto como esse em nossa sociedade (Ibidem). Em entrevista realizada em 2005, Rubens Pileggi Sá contou que o "Dia do Nada" possui uma relação com o seu processo de trabalho, com a sua "arte", que foi sempre aproximar, cada vez mais, a arte da vida (SÁ, 2005). Assim ele se expressa:

A partir de 1998, eu comecei a realizar alguns trabalhos em São Paulo, que se chamavam "Atitudes de Ocupação de Território"[...]. Então, 
vamos começar a trabalhar na rua, que é uma maneira de intervir na realidade concreta e material da vida. Em vez de ficar de costas para o mundo, refletindo a vida num quadro, de cavalete, eu vou ficar de frente para a vida, encará-la como material para o meu trabalho de arte. Aí, comecei a trabalhar com áreas de risco, idéias como "centro" e "periferia", "dentro" e "fora", espaços cheios e vazios. Tudo isso ligado a indigentes, mendigos, fumadores de "crack", entendeu? Eu ia ler o "Inferno" de Dante para eles, eu levava espelhos que eu roubava de casas que estavam para alugar de gente rica e vazia, para colocar em abrigos de pessoas sem-teto [...]. Eu mijava ao redor de alguns lugares, como um lobo que marca seu território, como um escultor que cria um espaço. Então, eu criava um espaço de urina e chamava aquilo lá de "fonte". Remetendo isso, a história da arte, à fontes famosas como as de Trevi, a de Duchamp. Enfim, a todas as fontes da arte como "fonte". $\mathrm{O}$ artista como fonte, não mais a fonte que o artista faz de escultura, porém, ele já como fonte, ele próprio sendo a fonte. Depois comecei a fazer alguns trabalhos aqui no Norte do Paraná, com essa coisa de latifúndio, de derrubada de matas. Eu fazia intervenções, sempre ligado à questão e aos elementos da propriedade. Esses sempre foram temas que me acompanharam. Também a questão do trabalho. O que é trabalho? O que não é trabalho? Aí eu venho desenvolvendo esse tipo de "trabalho" na rua, sem precisar da instituição para garantir que o que eu faço seja arte.. O meu cérebro era o meu ateliê [...]. Eu fiquei 15 anos fora dessa região. Antigamente, aqui era mais frio e depois quando retornei, esse calor "desgraçado". As propriedades eram menores, agora tinham virado latifúndios. Havia outros tipos de planta, apesar do café ser monocultura. Agora a soja é a monocultura. Também agrotóxicos em grande quantidade, a Monsanto, a questão da globalização com muito peso [...]. Dessa maneira, eu conversava muito com o meu amigo Marcelo, lá de Bela Vista do Paraíso. Então a gente pensava e discutia muito sobre essas teorias "conspiratórias". Como conseguir uma inserção no mundo de hoje, quer dizer, que não fosse de enfrentamento, mas de "atravessar por brechas". E no Rio de Janeiro, na sala da casa do artista Edson Barros, ele me disse que o dia que ficar deitado na rede for arte, então a relação arte e vida pode ser desfeita. Não precisa mais ficar separando o que é arte e o que é vida. Não preciso dizer que "tal coisa" é arte e vida, pois isso simplesmente vai fazer parte da continuidade do que eu sou. Matou aí! (Ibidem).

A partir disso, a noção de trabalho e de ócio foi decisiva na vida de Pileggi.

Por isso ele sempre se pergunta se é preciso trabalhar, é necessário o desenvolvimento econômico? O emprego? O progresso? A prosperidade? Existe muito mais indústria, muito mais produto do que a capacidade humana hoje de se consumir. A matéria-prima está acabando, mas os produtos estão aí, renovase cinco vezes mais produtos hoje, do que a própria humanidade pode consumir. Será que o trabalho enobrece mesmo? Questiona Pileggi.

O idealizador do "Dia do Nada”, justifica-se evocando filósofos, sociólogos e artistas. Cita Paul Lafargue, autor do ensaio intitulado O Direito à Preguiça. Dá ênfase também aos escritos de Bertrand Russel e, mais recentemente, às obras de Domenico de Masi. Além do mais, para ele, a idéia do ócio ou do trabalho não é uma questão negativa, pois em termos de Física, qualquer ponto 
que se desloca, que gasta energia de um ponto a outro, qualquer partícula que se desloca de um ponto a outro gasta energia. "Então, mesmo parado, alguma coisa em você está trabalhando. Tudo é trabalho! Nesse sentido não há vagabundagem absoluta." (Ibidem).

A idéia de "vazio" é também um outro tema que influencia esse artista. Ele explica que o próprio Dadaísmo é completamente niilista e influenciados por ele são o grupo "Fluxus", Yoko Onno, Bioy Casares, Andy Warhol, Yves Klein, entre outros. Esse último fez o Museu do Nada, que as pessoas chegam na Galeria, e aí não encontram nada lá. $\mathrm{O}$ vazio, como tema para arte não é uma novidade. Pileggi entende que para o Zen Budismo, o nada é o nirvana, é o máximo a que alguém pode chegar, é a iluminação búdica. Todas as religiões trabalham com o absoluto, e o nada, assim como o tudo, é absoluto, está ligado ao Eterno, à eternidade, ao éter, ao "Grande Vazio".

Profundamente influenciado por estas idéias, Pileggi "produz" desde 2002 o "Dia do Nada". É importante observar as mudanças e transformações desse evento (ele se torna mais uma performance, do que propriamente um evento), de 2002 a 2005. Entretanto, há uma transgressão à idéia de trabalho, que está presente em todas as edições.

\section{Considerações finais}

O que podemos perceber, no decorrer desse artigo, é que algumas pessoas, filosofias e movimentos de diversos períodos da história têm sido orientados por uma tendência de questionamentos, denúncias e transgressões, de inúmeras maneiras, à moral gregária da obediência e da passividade da maioria das pessoas que, habituadas a guiarem-se pelas convenções sociais, recusam e negam suas pulsões e desejos. Foi, e é preciso reagir, desprender-se desses vários hábitos que sufocam, no homem, o seu gênio criador e inventivo, tornando-o inapto para viver a vida em sua totalidade. É necessário entregar-se à aventura de viver experiências de toda ordem, de fazer da existência uma espécie de obra de arte, característica esta que é uma marca do sentimento trágico da vida, pois tudo é vivido em tensão, na incompletude permanente.

A própria existência desses vadios, vagabundos, libertinos, nômades, mendigos, lúbricos, errantes, artistas, pode ser traduzida pelo sair de si, pelo 
abrir-se a um outro, e esta experiência se manifesta e é reforçada por meio das inúmeras transgressões por eles praticadas. Ser fora de si é um modo de se abrir ao mundo e aos outros. Nesse sentido, os diversos "êxtases" antigos ou contemporâneos, de qualquer ordem: técnicos, culturais, musicais, afetivos, reafirmam o antigo desejo de circulação, de evasão. Circulação, movimento e transformações dos bens, das palavras, dos gestos, das atitudes, das opiniões, das identidades, do sexo que contaminam todo o tecido social.

Deste esse ponto de vista, podemos entender que somos e seremos entes em constante dispersão, com episódios provisórios e tênues de estabilidade. Somos sujeitos da pulsão, da transfiguração. Explosão que se vive em nível global, do imaginário coletivo, mas, também, como expressão existencial de cada singularidade. Por essa razão, é necessário que o homem do nosso tempo descubra a escassez da existência e viva no limite da imanência. O próprio universo é provisório e a pretendida estabilidade nada mais é que um momento fugaz. Compreender que nada é definitivo e que quando algo se fizer definitivo, ele, o homem, não mais será.

\section{Bibliografia}

AGUIAR, Iosito. François Villon: un homme de douleur et sont chemin d'épines. Disponível em: <http://www.revista.agulha.nom.br/ag4villon.html >. Acesso em 05 maio 2005.

BERNARDI, Carlos. Diógenes, Foucault e a prática da parhesia. Disponível em: <http://www.rubedo.psc.br/artigosb/diogenes.htm>. Acesso em: 05 maio 2005 .

DEBÓRD, Guy. A sociedade do espetáculo. Rio de Janeiro: Contraponto, 1997.

DELEUZE, Gilles. Conversações. Rio de Janeiro: Ed. 34, 1992.

DUARTE, José. Comentários à lei das contravenções penais. Vol II, parte especial. 2. ed. Rio de Janeiro: Forense, 1956.

FOUCAULT, Michel. Estética: literatura e pintura, música e cinema. Organização e seleção de textos, Manoel Barros da Motta; tradução, Inês Autran Dourado Barbosa. Rio de Janeiro: Forense Universitária, 2001.

Arqueologia das Ciências e História dos Sistemas de Pensamento. Organização e seleção de textos, Manoel Barros da Motta; tradução, Inês Autran Dourado Barbosa. 2. ed. Rio de Janeiro: Forense Universitária, 2005.

O que é um autor? Trad. José A. Bragança de Miranda \& Antonio Fernando Cascais. Lisboa: Passagens, 1992.

GEREMEK, Bronislaw. Os filhos de Caim: vagabundos e miseráveis na literatura européia 1400-1700. São Paulo: Companhia das Letras, 1995. 
GOULET-CAZÉ, Marie-Odile. Cínicos: O cinismo antigo e sua posteridade. Trad. de Paulo Neves. In: ANTO-SPERBER, Monique. Dicionário de ética e filosofia moral. v. 1. São Leopoldo: Ed. da UNISINOS, 2003.

KARVAT, Erivan Cassiano. A Sociedade do Trabalho: discursos e práticas de controle sobre a mendicidade e vadiagem em Curitiba, 1890-1933. Curitiba: Aos Quatro Ventos, 1998.

MAFFESOLI, Michel. Sobre o Nomadismo: vagabundagens pós-modernas. Rio de Janeiro: Record, 2001.

MANNHEIM, Karl. Diagnóstico de nosso tempo. Tradução de Octávio Alves Velho. Rio de Janeiro: Zahar, 1959.

MARTINS, Silvia Helena Zanirato. Artifíces do ócio: mendigos e vadios em São Paulo (1933-1942). Londrina: EDUEL, 1998.

NASCIMENTO, Wanderson Flor do. Nos Rastros de Foucault: ética e subjetivação. Disponível em: <http://www.unb.br/fe/tef/filoesco/foucault/arto2.html>. Acesso em 15 fev. 2006.

NIETZSCHE, Frederich. W. O nascimento da tragédia ou helenismo e pessimismo. 2. ed. São Paulo: Companhia das Letras, 2003.

A Gaia Ciência, IN: Obras Incompletas. São Paulo: Nova Cultural, 1999.

RIBEIRO, Lúcio Ronaldo Pereira. Vadiagem. Disponível em: <www.ambitojuridico.com.br/aj/dpooo2.html>. Acesso em 03 maio 2004.

ROSENFELD, A. Romantismo e Classicismo. IN: GUINSBURG, J. (Org.). $O$ Romantismo. 3. ed. São Paulo: Perspectiva, 1993. pp. 261-275.

SÁ, Rubens Pileggi. Entrevista sobre o evento "Dia do Nada". (Realização, gravação e transcrição) de Rodrigo Poreli M. Bueno. Londrina: 2005. 2 fitas cassetes (90 min.).

SATO, Nelson. Performance - Viva o "ócio criativo". Disponível em: $<$ http://www.bonde.com.br/folha/folhad.php?id=165\&dt=20060502>. Acesso em 02 maio de 2006.

SÊNECA. Aprendendo a Viver. Trad. Carlos Nougué. São Paulo: Martins Fontes, 2002.

Colaboração recebida em 07/07/2008 e aprovada em 20/11/2008. 